\title{
CORRIGENDUM
}

\section{Continuous real-time measurement of tumor necrosis factor- $\alpha$ converting enzyme activity on live cells}

\author{
Montserrat Alvarez-Iglesias, Gareth Wayne, Kieran P O'Dea, Augustin Amour and Masao Takata
}

Laboratory Investigation (2009) 89, 106; doi:10.1038/labinvest.2008.118

Correction to: Laboratory Investigation (2005) 85, 14401448. doi:10.1038/labinvest. 3700340

In this article, the author has made the following corrections in the text:

Page 1442, right column, first and second paragraphs of Results (FAM-TAMRA Peptide Cleavage by Recombinant TACE and ADAM-10)

We first tested the validity of the FAM-TAMRA TNF peptide in vitro using recombinant enzymes. Peptide cleavage was measured by real-time monitoring of fluorescent signal using a spectrofluorimeter. Hydrolysis of $5 \mu \mathrm{M}$ FAM-TAMRA TNF peptide by $0.7 \mathrm{nM}$ rTACE produced a fourfold increase above the background fluorescent signal over $60 \mathrm{~min}$ (Figure 1a). The reaction curve was linear over time with the rate of peptide cleavage effectively constant. No peptide cleavage was observed in the absence of enzyme, and complete inhibition of the cleavage was achieved by $>6 \mu \mathrm{M}$ of GM6001 with an
IC50 of $20.6 \pm 1.2$ (s.e.) $\mathrm{nM}(n=4)$. The assay was highly sensitive, able to detect subnanomolar concentrations of TACE with a $k_{\text {cat }} / K_{\mathrm{m}}$ of $9.89( \pm 0.35) \times 10^{3} \mathrm{M}^{-1} \mathrm{~s}^{-1}$ being determined $(n=8)$. The peptide could not be dissolved in the buffer solution at concentrations high enough to allow accurate determination of $K_{\mathrm{m}}$ and $V_{\max }$.

ADAM-10, another protease of the ADAM family, has been reported to cleave TNF-based peptides. ${ }^{6}$ Hydrolysis of $5 \mu \mathrm{M}$ FAM-TAMRA TNF peptide by $1.7 \mathrm{nM}$ rADAM-10 over 60 min produced a 2.3 -fold increase of the fluorescent signal above the background (Figure 1a). However, $k_{\text {cat }} / K_{\mathrm{m}}$ was 1.23 $( \pm 0.04) \times 10^{3} \mathrm{M}^{-1} \mathrm{~s}^{-1}$ for rADAM-10 $(n=8)$, that is, more than eightfold lower than for TACE, indicating that ADAM10 is less efficient at cleaving this peptide.

The corrections to enzyme concentrations described above also apply to Figure 1, which should correctly read:

Figure 1 Validation of the FAM-TAMRA TNF peptide-based assay using recombinant enzymes. (a) Typical reaction curves of the peptide cleavage by $\mathrm{rTACE}(\bigcirc)(0.7 \mathrm{nM})$ and $\mathrm{rADAM}-10(\mathrm{O})(1.7 \mathrm{nM})$. 